\title{
Hormones and Cell Regulation
}

\section{Hormones et Régulation Cellulaire}

Proceedings of the 12th INSERM European Symposium on Hormones and Cell Regulation, held at Mont Sainte-Odile (France), October 1987

Sponsored by the Institut National de la Santé et de la Recherche Médicale (INSERM)

Edited by

J. Nunez

J.E. Dumont

E. Carafoli

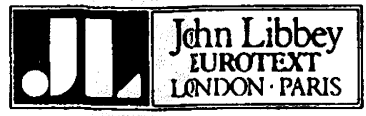




\title{
Contents
}

\author{
Sommaire
}

V Foreword

VI Avant-propos

VII List of participants

VIII Liste des participants

POLYPEPTIDES AND OTHER HORMONES

POLYPEPTIDES ET AUTRES HORMONES

3 F. Murad

Atrial natriuretic peptide, endothelium-dependent vasodilators and nitrovasodilators, role of guanylate cyclase and cyclic GMP in their actions.

Le facteur nalriurétique atrial et autres vasodilatateurs : rôle de la guanylale cyclase et du GMP cyclique dans leurs aclions.

13 F. Morel and A. Doucet

Hormonal control of $\mathrm{Na} / \mathrm{K}$-ATPase.

Contrôle hormonal de la $\mathrm{Na} / \mathrm{K}$-ATPase.

31 P. Corvol and J. Menard

Renin inhibition: strategies for the design of renin inhibitors as deduced from the renin gene structure.

Inhibition de la rénine : stratégies pour la conception d'inhibiteurs de la rénine déduils de la structure du gène rénine.

43 R. Bosselut, C. Glineur, Y. Goldberg, A. Begue and J. Ghysdael

Thyroid hormone receptors and the erbA family of genes: structural and functional relationships.

Récepteurs des hormones thyroïdiennes el la famille de gènes erbA : relations structurales et fonctionnelles.

\section{INTRACELLULAR CLASSIFYING OF PROTEINS \\ TRIAGE INTRACELLULAIRE DES PROTEINES}

63 N. Pfanner, F-U. Hartl and W. Neupert

Protein transport into mitochondria : a multi-step process.

Transport des protéines dans les milochondries : un processus à plusicurs élapes.

ION CHANNELS

CANAUX IONIQUES

73 V. Flockerzi

Molecular properties of voltage activated calcium channels.

Propriétés moléculaires des canaux calcium activés par le voltage.

89 W. Stühmer, B. Keller, G. Lippe and M.C. Sorgato

The outer and inner membranes of mice liver giant mitochondria can be patched clamped : high conductance ion channels are present in both membranes.

Les membranes externes et internes des niitochondries géantes de foie de souris peuvent être "patched clamped": des canaux ioniques de haute conductance sont présents dans les deux types de membranes. 
The cGMP-gated channel from vertebrate rod photoreceptors.

Le canal ouvert par le GMPc des photorécepleurs des bâlonnets de vertébrés.

115 M. Fosset, J. de Weille, M. Lazdunski, H. Schmid-Antomarchi and H. Bernardi The receptor for antidiabetic sulfonylureas is the ATP-modulated $\mathrm{K}^{+}$channel Le récepleur des sulfonylurées antidiabétiques est le canal $K^{+}$modulé par l'ATP.

127 H. Betz

Neurotransmitter-gated chloride channels in the central nervous system.

Canaux chlorures ouverts par les neurotransmetteurs dans le système nerveux central.

CALCIUM AS A SIGNAL CARRIER

LE CALCIUM COMME VECTEUR DE SIGNAL

135 P. Cobbold, R. Cuthbertson and N. Woods

The generation of repetitive free calcium transients in a hormone-stimulated hepatocyte.

Génération de transitions répétitives de calcium libre par des hépalocytes stimulés par des hormones.

147 M.R. Crompton, R.H. Newman, J.M. Hexham and M.J. Crumpton

p. 68: a new member of the lipocortin family of membrane-associated $\mathrm{Ca}^{2+}$-binding proteins.

p. 68: un nouveau membre, parmi les proléines associées aux membranes et liant le calcium, appartenant à la famille des lipocortines.

155 T. Jean

The release of calcium from endoplasmic reticulum : effect of inositol 1,4,5-trisphosphate and guanine nucleotides.

La libération du calcium à partir du réticulum endoplasmique : effet des nucléotides guanyliques et de l'inositol 1,4,5-triphosphate.

167 S. Hashimoto, B. Bruno, P. Volpe, F. Zorzato, T. Pozzan, K.H. Krause, D.P. Lew and J. Meldolesi.

On the nature and function of the calciosome, a cytoplasmic organelle containing calsequestrin-like protein(s) which is expressed in non-muscle cells.

Sur la nature el la fonction du calciosome, une organclle cytoplasmique contenant une protéine(s) semblable à la calsequestrine qui est exprimée dans les cellules non musculaires.

CALCIUM REGULATING HORMONES

HORMONES REGULATRICES DU CALCIUM

183 A. Edelman, J. Fritsch, C.L. Thil, M. Garabédian, T. Anagnostopoulos and S. Balsan

Membrane effects of parathyroid hormone and vitamin D metabolites in target cells. Effets membranaires de la parathormone et des mélabolites de la vilamine $D$ sur les cellules cibles.

199 M. Thomasset, J.M. Dupret, N. Lomri, M. Warembourg, P. Brun, A. Brehier and C. Perret

Vitamine D-induced Ca-binding protein gene: expression, regulation and structure. Le gène de la proléine lianl le calcium induit par la vilamine D: expression, régulation el structure.

215 E.F. Nemeth and A. Scarpa

Calcium signals and the regulation of parathyroid hormone secretion.

Signaux calcium et régulation de la sécrétion de la paralhormone.

227 W. Born and J.A. Fischer

Calcitonin gene products : biosynthesis and biological properties.

Produits du gène calcilonine: biosynthèse et propriétés biologiques. 


\title{
Protein transport into mitochondria: a multi-step process
}

\author{
Nikolaus Pfanner, Franz-Ulrich Hartl and Walter Neupert
}

Instilul für Physiologische Chemie, Universitäl Müchen, D-8000 Müchen 2, FRG

\begin{abstract}
The transport of precursor proteins from the cytoplasm into mitochondria can be resolved into several steps. Precursor proteins can be reversibly accunulated at distinct stages of the import pathway: at the level of binding to the liitochondrial surface, in contact sites between outer and inner mitochondrial membranes, and in the mitochondrial motrix. Import intermediates can be trapped by a number of methods: lowering the temperatures or the levels of nucleoside triphosphates in the import reactions, dissipation of the mitochondrial nembrane potential, and inhibition of the matrix-located processing peptidasc. The following conclusions may be drawn (i) precursors specifically bind to receptor proteins on the mitochondrial surface; ( $i i$ ) import occurs at translocation contact sites; ( $i i_{i}$ ) proteolytic processing is not required for iliport into the matrix; and (iv) several precursors destined for the intermembrane space are first completely inporled into the matrix and are then retranslocated across the inner nembrane.
\end{abstract}

\section{KEY WORDS}

¿1itochondria, protein import, receptors, contact sites, protein sorting

\section{INTRODUCTION!}

The translocation of precursor proteins from the cytoplasm into milochondrio is o multi-step process (for review see Ref. 1). llany precursor proteins contain amino-terminal presequences which carry specific information for targeting lo mitochondria (for review see Ref. 2). Nucleoside triphosphales are required lo keep cytosolic precursors in an unfolded conformation $(3,4)$. The precursors specifically interact with proteinaceous binding sites on the mitochondrial surface (5-9). Import into or across the inner membrane occurs at contact sites between both membranes $(8,10-12)$ and requires a membrane potential $\Delta \psi$ across the inner membrane (13-16). Presequences are proteolytically removed by the processing peptidase located in the mitochondrial matrix (17-20). The proteins are sorted to their final intramitochondrial location and are often assembled into multi-subunit complexes. 
How can the complex process of mitochondrial protein import be studied in detail? We decided to dissect the import reaction into several distinct steps. Precursor proteins are accumulated at distinct stages of their import pathway and are further imported after release of the block. Thus, translocation intermediates are generated. This allows us to investigate defined steps of protein import.

\section{METHODS TO GENERATE TRANSLOCATION INTERMEDIATES}

The principle method for obtaining import intermediates is to slow down or to prevent distinct reactions which occur on the import pathway of a precursor. This block should be reversible, as it is necessary that it can be relieved and that the precursors then can move further on the import pathway. This demonstrates that the trapped intermediate is an authentic inport intermediate, i.e. it is on the correct assembly pathway. In most experiments, mitochondria isolated from the fungus Neurospora crassa and precursor proteins synthesized in rabbit reticulocyte lysates are used. Several of the described translocation intermediates were also demonstrated in in vivo experiments.

One important method is to lower the temperature of the import reaction. The half-times of many reactions are thereby prolonged and thus the import is slowed down. This allows the transient trapping of precursors in contact sites between outer and inner membranes (10).

Nucleoside triphosphates (NTPs) are required for unfolding cytosolic precursors. With lowered levels of NTPs, precursors are only partially unfolded and thereby can be accumulated at the stage of specific binding or in translocation contact sites (3).

The membrane potential $\Delta \psi$ is required for the initial entrance of precursors into the inner membrane. In the absence of a membrane polential several precursors can still specifically bind to the outer mitochondrial membrane. Upon reestablishing $\Delta \psi$, the precursors are imported from their binding sites $(5,21)$.

Finally, the processing peptidase in the milochondrial matrix is dependent on divalent cations. Membrane-permeable chelators, such as ortho-phenanthroline, inhibit the processing activity in intact mitochondria. Precursors can thus be imported into the mitochondrial matrix without the removal of their amino-terminul presequences $(11,22)$.

\section{IMPORT INTERMEDIATES AT THE LEVEL OF SPECIFIC BINDING}

At low temperatures $\left(0^{\circ}\right.$ to $\left.4^{\circ} \mathrm{C}\right)$, the precursor of the outer membrane protein porin specifically binds to the milochondrial surface. The binding sites are saturable, and the affinity constant has been determined. The precursor can be completely imported and assembled after raising the temperature to $25^{\circ} \mathrm{C}$.

Furthermore, the binding step is inhibited by a mild protease-pretreatment of the mitochondria (9). These data strongly suggest the involvement of a proteinaceous high affinily binding site (receptor) in the import of porin into the outer menbrane.

After dissipalion of the membrane polential, the precursor of the inner membrane protein ADP/ATP carrier still binds to the outer mitochondrial membrane. Upon reestablishment of $\Delta \psi$, the $A$.'ATP carrier is imported from the 
binding sites without prior release from the mitochondrial membranes (5). When binding is performed at $25^{\circ} \mathrm{C}$, the precursor inserts into saturable proteinaceous sites in the outer membrane, which are beyond the initial protease-sensitive binding sites. However, when the dissipation of $\Delta \psi$ is combined with a lowering of the temperature (to $2^{\circ} \mathrm{C}$ ) or of the levels of ATP, the precursor remains on the surface of the mitochondria accessible to externally added proteases. Raising the temperature or the levels of ATP leads to insertion of the precursor into the second binding sites described above ( 3 , 8 ). These studies show the existence of two subsequent binding sites on the import pathivay of ADP/ATP carrier.

Similarly, the precursor of F-ATPase subunit 9 (an inner membrane protein) specifically binds to mitochondria in the absence of $\Delta \psi$, and can be imported, from the binding sites, in the presence of $\Delta \psi$. The same result is obtained for a fusion protein between the complete subunit. 9 precursor and cytosolic dihydrofolate reductase (DHFR). Two fusion proteins between the presequence of subunit 9 and DHFR are imported in the presence of $\Delta \psi$. In the absence of $\Delta \psi$, however, their specific binding to the mitochondrial surface is very weak. Furthermore, the import kinetics of the two precursors lacking the (hydrophobic) mature part of subunit 9 are slower than those of the two precursors containing the mature part. Upon studying the efficiency of specific binding and the kinetics of import of other precursor proteins, we arrived at the following proposal: mitochondrial precursor proteins can be grouped into at least two different classes. Class I precursors contain a hydrophobic stretch of about 20 amino acid residues, show a strong interaction with binding sites on the mitochondrial surface and a rapid import. Class II precursors lack a long hydrophobic stretch, show only a weak interaction with binding sites and a slow import (21). These studies suggest that (hydrophobic) 'assistant' sequences increase the affinity of binding to receptor sites and support a rapic iliport of precursors.

\section{IMPORT INTERMEDIATES IN TRANSLOCATION CONTACT SITES}

Sites of close contact between mitochondrial outer and inner membranes were described many years ago (23). The accunilation of precursor proteins in contact sites assigned, for the first time, a biochemical function to these sites by demonstrating their involvement in mitochondial protein import (10). Protein import was performed at low temperatures $\left(2^{\circ}\right.$ to $\left.12^{\circ} \mathrm{C}\right)$ or at low levels of nucleoside triphosphates. Consequentiy, the amino-terminal portions of precursor proteins ivere translocated into the matrix, where the presequences were cleaved off by the processing peptidase. Major portions of the precursors, however, were still outside the outer membrane as they were accessible to protcases or to antibodies added to isolated mitochondria. Thus, the precursor proteins were reaching from the outside of the outer membrane into the matrix thereby spanning sites of close conlact between both membranes (translocation contact sites) $(3,8,10-12)$. The translocation intermediates with bound antibodies were decorated with protein-A-gold particles. Electron microscopy allowed their visualizalion and served to confirm that the contact sites previously described morphologically represented the contact sites now defined biochemically (12). The translocation intermediates in contact sites are accessible to aqueous perturbants, such as alkali or urea. Thus, protein import does not seem to directly occur through the lipid bilayer, but rather through a hydrophilic (probably proteinaceous) environment (24).

Only the initial entrance of precursors into contact sites requires the membrane potential across the inner meribrane; the colipletion of protein transport into or across the inner membrane does not require the membrane 
potential (10). Furthermore, it was demonstrated that only the electrical component $\Delta \psi$ of the total protonriotive force was necessary for protein import (15). These results led us to propose that the membrane potential $\Delta \psi$ exerts an electrophoretic effect on positively charjed regions of the precursor proteins (such as the presequences).

\section{IMPORT INTERMEDIATES IN THE MITOCHONDRIAL MATRIX}

Upon import into mitochondria, the amino-terminal presequences of precursor proteins are cleaved off by the metal-dependent processing peptidase in the natrix. Proteolytic processing, however, is not a prerequisite for

translocation of precursors across the mitochondrial membranes (22). When processing activity is blocked by metal chelators, precursors of subunits 2 and 9 of F F -ATPase are still imported in vitro into a position protecled against externally added protease.

Complete import in the absence of proteolytic processing can also be shown for precursors destined for the mitochondrial intermembrane space. The ability to block the processing peptidase is used as a tool to dissect the import pathway of these proteins into intermediate steps. Such experiments with the Rieske $\mathrm{Fe} / \mathrm{S}$-protein of the $\mathrm{bc}$-complex, a protein located at the outer surface of the inner membrane, had a surprising result $(11,25)$. Following inhibition of the processing peptidase precursor of Fe/S-protein is accumulated as a soluble species in the mitochondrial matrix, as ravealed by digitonin fractionation of mitochondria. Upon reactivation of the processing peptidase by divalent cations, the precursor is processed to the mature subunit which is correctly sorted into the internembrane space. The Fe/S-protein, thus, during import and sorting, crosses the inner membrane twice. Interestingly, proteolytic processing of the precursor occurs in two steps. The first cleavage is performed by the processing peptidase and results in the formation of an intermediate-sized species with an eight amino acid residue amino-terminal extension. The second processing step also occurs inside the inner membrane and is very likely dependent on the attachment of the $2 \mathrm{Fe}-2 \mathrm{~S}$ cluster to the molecule (Hartl and Neupert, unpublished). Addition of the strong iron chelator ortho-phenanthroline during inport causes accumulation of intermediate-sized $\mathrm{Fe} / \mathrm{S}$-protein in the matrix.

Similar results are obtained for the import of cytochrome $b_{2}$ and cytochrome $c_{1}$ (26). Cytochrome $b_{2}$ is a soluble component of the intermembrane space while cytochrome $c_{\uparrow}$ is anchored to the inner membrane but faces the intermenbrane space with a large hydrophilic domain. The presequences of their precursors can be divided into two parts. The amino-terminal part contains several positive charges and exhibits the typical features of mitochondrial targeting sequences, however, the carboxy-terminal parts (in contrast to the precursor of $\mathrm{Fe} / \mathrm{S}$-protein) contain a hydrophobic stretch of about 20 amino acid residues. Precursors of both cytochrome $b_{2}$ and cylochrome $c_{1}$ are first imported via translocation contact sites into the matrix of mitochondria. There the action of processing peptidase generates the respective intermediate-sized forms where the amino-terminal peptide extensions still contain the hydrophobic part of the presequence. These intermediate-sized species are subsequently translocated back across the inner membrane into the intermembrane space. Unlike the Fe/S-protein, processing to the mature-sized forms occurs at the outer surface of the inner membrane. Targeting information for the reverse translocation very likely resides in the hydrophobic prepiece of the intermediates. 
He suggest that the mechanism of the export from the mitochondrial matrix shares a common origin with the mechanism of protein export from the cytoplasm to the periplasmic space in procaryotes. In light of the hypothes is for the endosymbiotic origin of mitochondria, one may assume that gene transfer from the endosymiont to the nucleus of the host cell has occurred during development to mitochondria. Import via translocation contact sites brings precursors back onto their ancestral assembly pathway which is still followed with regard to export from the mitochondrial matrix (corresponding to the bacterial cytoplasm) across the inner membrane (corresponding to the bacterial plasma niembrane) ("Conservative sorting hypothesis").

\section{PERSPECTIVES}

Translocation intermediates of precursor proteins accumulated at distinct stages of mitochondrial protein import are very useful not only for elucidating functional characteristics of protein transport, but are also a prerequisite for the identification and purification of components of the import machinery. Import intermediates trapped at the level of binding serve as the test system for identifying receptors, either via cross-linking reagents or by extracting the binding sites with mild detergents and reconstituting them into liposomes (9). Translocation intermediates in contact sites are the marker proteins for enriching contact site components either by subfractionation of mitochondria (sonication (12) or use of mild detergents) or by cross-linking. Thus, translocation intermediates are powerful tools for investigating mitochondrial protein import at the molecular level.

\section{ACKNOULEDG!IENT}

We thank R.A. Stuart for critically reading the manuscript.

\section{REFERENCES}

1. Pfanner, N., and Neupert, W. (1987): Biogenesis of mitochondrial energy transducing complexes. Curr. Top. Bioenerg. 15, 177-219.

2. Hurt, E.C., and van Loon, A.P.G.M. (1986): How proteins find mitochondria and intramitochondrial compartments. Trends Biochem. Sci. 11. 204-207.

3. Pfanner, N.., Tropschug, M., and Neupert, H. (1987): Mitochondrial protein import: nucleoside triphosphates are involved in conferring import-competence to precursors. Ce11 49, 815-823.

4. Verner, K., and Schatz, G. (1987): Import of an incompletely folded precursor protein into isolated mitochondria requires an energized inner membrane, but no added ATP. EMBO J. 6, 2449-2456.

5. Zwizinski, C., Schleyer, M., and Neupert, W. (1983): Transfer of proteins into mitochondria. Precursor to the ADP/ATP carrier binds to receptor sites on isolated mitochondria. J. 3iol. Chem. 258, 4071-4074.

5. Zwizinski, C., Schleyer, M., and Neupert, W. (1984): Proteinaceous receptors for the import of mitochondrial precursor proteins. J. Biol. Chem. 259, 7850-7856.

7. Riezman, H., Hay, R., Witte, C., Nelson, N., and Schatz, G. (1983): Yeast mitochondrial outer membrane specifically binds cytoplasmically-synthesized precursors of mitochondrial proteins. EMBO J. 2, 1113-1118.

8. Pfanner, N., and Neupert. W. (1987): Distinct steps in the import of ADP/ATP carrier into mitochondria. J. Biol. Chem. 262, 7528-7536.

9. Pfaller, R., and Neupert, !N. (1987): High-affinity binding sites involved in the import of porin into mitochondria. EMBO J. $\underline{6}, 2635-2642$. 
10. Schleyer, 1.., and Meupert, W. (1985): Transport of proteins into mitochondria: translocational intermediates spanning contact sites between outer and inner membranes. Cell 43, 339-350.

11. Hart7, F.-U., Schmidt, B., Wachter, E., Weiss, H., and Meupert, W. (1985): Transport into mitochondria and intramitochondrial sorting of the $\mathrm{Fe} / \mathrm{S}$-protein of ubiquinol cytochrome c reductase. Cell 47 , 939-951.

12. Schwaiger, M., Herzog, V., and Neupert, H. (1987): Characterization of translocation contact sites involved in the import of mitochondrial proteins. J. Cell Biol. 105, 235-245.

13. Schleyer, H., Schmidt, 3., and Neupert, W. (1982): Requirement of a membrane potential for the posttranslational transfer of proteins into mitochondria. Eur. J. Biochem. 125, 109-115.

14. Kolanski, D.M., Conboy, J.G., Fenton, W.A., and Rosenberg, L.E. (1982): Energy-dependent translocation of the precursor of ornithine transcarbamylase by isolated rat liver mitochondria. J. Biol. Chem. 257, 8467-8471.

15. Gasser, S.M., Dauri, G., and Schatz, G. (1982): Import of proteins into mitochondria. Energy-dependent uptake of precursors by isolated mitochondria. J. Biol. Chem. 257, 13034-13041.

10. Pfanner, N., and Neupert, W. (i985): Transport of proteins into mitochondria: a potassium diffusion potential is able to drive the import of ADP/ATP carrier. EMBO J. 4, 2819-2825.

17. Böhni, P., Gasser, S., Leaver, C., and Schatz, G. (1980): A matrix-localized mitochondrial protease processing cytoplasmically-made precursors to mitochondrial proteins. In The Organization and Expression of the !itochondrial Genome (Kroon, A.M., and Saccone, C., eds.), 423-433. Elsevier/North-4o11and, Amsterdan.

18. Conboy, J.G., Fenton, W.A., and Rosenberg, L.E. (1982): Processing of pre-ornithine transcarbanylase requiras a zinc-dependent protease localized to the mitochondrial matrix. Biochem. 3iophys. Res. Commun. 105, 1-7.

19. icAda, P.C., and Douglas, M.G. (1982): A neutra metallo-endoprotease involved in the processing of an F -ATPase subunit precursor in mitochondria. J. Biol. Chen. 257, 3177-3182.

20. Schnidt, B., wachter, E., Sebald, W., and Neupert, W. (1984): Processing peptidase of Neurospora mitochondria. Two-step cleavage of imported ATPase subunit 9. Eur. J. Biochem. 144, 581-583.

21. Pfanner, N., I!iul 7 er, 4.K., Harmey, :1.A., and Neupert, 4. (1987): ilitochondrial protein import: involvenent of the mature part of a cleavable precursor protein in the binding to receptor sites. EM130 J. 6 . $3449-3454$.

22. Zwizinski, C., and Neupert, W. (1983): Precursor proteins are transported into mitochondria in the absence of proleolylic clcavage of the additional sequences. J. Biol. Chem. 253, 13340-13346.

23. Hackenbrock, C.R. (1958): Chemical and physical fixation of isolated mitochondria in low-energy and high-energy states. Proc. Natl. Acad. Sci. USA 61, 589-502.

24. Pfanner, N., Hart1, F.-U., Guiard, 3., and Neupert, !.. (1987): Mitochondrial precursor proteins are iliported through a hydrophilic membrane environnent. Eur. J. Bincheri.., in press.

25. Hart1, F.-U., Pfanner, N., and Neupert, W. (1987): Translocation intermediates on the import pathway of proteins into mitochondria. Biocheril. Soc. Trans. 15, 95-97.

26. Hart1, F. -U., Ostermann, J., Suiard, 3., and Meuperl, W. (1987): Successive translocation into and out of the mitochondrial matrix: targetting of proteins to the intermembrane space by a bipartite signal peptide. Cell, in press. 


\section{Résumé}

Il est possible de distinguer plusieurs étapes du transport des protéines précurseurs du cytoplasme dans la mitochondrie. Les protéines précurseurs peuvent être accumulées à diverses étapes des voies d'importation: au niveau de la liaison sur la surface mitochondriale, des sites de contact entre membrane externe et interne mitochondriale et dans le matrice mitochondriale. Des intermédiaires d'importation peuvent être bloqués par plusieurs méthodes: diminution de la température ou des niveaux de nucléosides triphosphates dans les réactions d'importation, dissipation du potentiel de membrane mitochondriale et inhibition de la peptidase responsable de la transformation qui est localisée dans la matrice. Les conclusions suivantes peuvent être déduites: 1) les précurseurs se lient spécifiquement aux protéines réceptrices sur la surface mitochondriale; 2) l'importation intervient sur des sites de contact de translocation; 3) une transformation protélytique n'est pas nécessaire pour que l'importation dans la matrice puisse intervenir; 4) plusieurs précurseurs dont la destination est l'espace intermembranaire sont d'abord complètement importés dans la matrice pour être ensuite retransloqués à travers la membrane interne. 